\title{
SICKNESS PRESENCE AND STRESSFUL LIFE EVENTS OF HEALTH CARE WORKERS
}

\author{
Alenka Škerjanc, Metoda Dodič Fikfak \\ University Medical Centre, Clinical Institute of Occupational, Traffic and Sports Medicine, Ljubljana, Slovenia
}

\begin{abstract}
SUMMARY
Aim: The aim of the study is to investigate the relationship between sickness presence and stressful life events among health care workers.

Methods: Data were gathered from all health care workers at the University Medical Centre Ljubljana employed there in the period between 1 January 2010 and 31 December 2010. Each employee obtained a questionnaire composed of two standardized international questionnaires.

Results: There were $57 \%$ of sickness present health care workers among the participants. The sickness present reported to have more diseases of family member than the non-sickness present $(\mathrm{OR}=1.5 ; 95 \% \mathrm{Cl}=1.2-2.0)$, loan $(\mathrm{OR}=1.4 ; 95 \% \mathrm{Cl}=1.1-1.6)$, their partner lost job $(\mathrm{OR}=1.4$; $95 \% \mathrm{Cl}=1.0-1.8)$, or they changed the place of living $(\mathrm{OR}=1.4 ; 95 \% \mathrm{Cl}=1.0-2.0)$.

Conclusions: The results of the study indicate that stressful life events with economic consequences might have an important influence on sickness presence.
\end{abstract}

Key words: sickness presence, health care workers, stressful life events

Address for correspondence: A. Škerjanc, University Medical Centre, Clinical Institute of Occupational, Traffic and Sports Medicine, Poljanski nasip 58, 1000 Ljubljana, Slovenia. E-mail: alenka.skerjanc@gmail.com

\section{INTRODUCTION}

In previously published studies the data on sick leave show that $30-40 \%$ of employees were not on sick leave during oneyear observation period $(1,2)$. A varied group ranging from employees who are actually healthy and do not have any healthrelated problems to those who feel sick but work nevertheless belong to this group. Sickness presence is the presence of workers at work when they feel so sick that they should be on sick leave (3-7). The latter include those with a lower social status, fixed-term employment or those threatened with dismissal from work, employees with more demanding and responsible work, and those who can arrange work by themselves and have low possibility of replacement at work $(2-4,7-10)$. One of important risk factors are financial difficulties $(4,11,12)$. Political changes followed by economic changes and restructuring in Eastern European countries have led to unsecured jobs and changed workers' behaviour (13). Workers started to avoid taking sickness leave even when they were sick, thus the risk of sickness presence is higher in case of job insecurity $(14,15)$. The researchers assessed higher odds for sickness presence in educational and medical institutions $(2,3)$. It was discovered that the level of sickness presence among health care professionals is associated with time pressure $(2,8,16,17)$, lack of personnel or the inability to replace a co-worker at work $(2,16)$, low work experience and dissatisfaction at work (17). The available literature does not provide data on association between stressful life events and the extent of sickness presence among health care workers. Therefore, the objective of this study was to assess the relationship between stressful life events and sickness presence among health care workers at the University Medical Centre Ljubljana (UMC Ljubljana).

\section{MATERIALS AND METHODS}

\section{Study Population}

The study was designed as a cross-sectional study. Out of 7,176 workers who were continuously employed at the UMC Ljubljana in the period between 1 January 2010 and 31 December 2010, the following employees were excluded: those who were on sick leave and/or maternity leave for more than six months, all those who were employed at the UMC Ljubljana for fewer than twelve months and those employed in technical services. The observed population amounted to 5,865 health care workers.

The outcome variable was sickness presence. The sickness present were defined as workers who were present at work at least two or more times in 2010 when sick and the non-sickness present were defined as workers who were never or at most once present at work when sick (2).

\section{Research Tools and Course of Study}

For the purpose of the study, a short questionnaire consisting of the questions taken from two international standardized and validated questionnaires was prepared $(3,18)$. The questionnaire contained questions related to demographic factors (sex, age, education, children, current smoking, sport participation, net salary) and some stressful life events associated with variables related to death of close family member, divorce, marriage, birth of a child, child leaving home, disease of a family member, change of workplace, change of responsibility at the workplace, change in working time, additional adult education, change in the employment status of a partner, loan, change of living conditions, change of residency, change in recreation, vacation. 
The questionnaires were distributed to all workers at the UMC Ljubljana in the second half of January 2011 with the help of senior nursing officers. We enclosed an envelope for the answer and a cover letter. The questionnaires were numbered by codes. Informed consent was signed by all participants who answered the questionnaire. Sealed envelopes with answered questionnaires were collected in special boxes by senior nursing officers and the couriers or the participants themselves took them to the Clinical Institute of Occupational, Traffic and Sports Medicine. The UMC Ljubljana Newspaper, No. 2, 2011, published an article describing the study and its aims in order to additionally encourage employees to answer the questionnaire. All those whose answers had not been received by the end of April 2011 were sent the questionnaires once again in May 2011 together with a request to answer them.

\section{Statistical Analysis}

Besides descriptive statistical methods univariate and multivariate logistic regression was used to analyse the association between sickness presence and the selected risk factors for sickness presence: gender (male, female), age (less than 50 years, 50 years or more), education (secondary or less, higher or university), children (no, yes), current smoker (no, yes), sport participation (never, yes), net salary $<1,000$ EUR (no, yes), each selected stressful life event (no, yes). The SPSS program, version 20.0, was used to perform the statistical analysis.

\section{RESULTS}

The questionnaire was completely answered by 3,379 health workers $(57.6 \%)$ with a mean age of 41.6 years $(\mathrm{SD}+10.2)$. Further details are presented in Table 1. As in other studies more women than men filled in the questionnaire $(5,19)$. Those younger than 50 years responded to the questionnaire slightly more frequently while the educational level did not yield any statistically significant differences $(\mathrm{p}>0.05)$.

Among 3,379 workers, 1,927 were sickness present (57.0\%) and 1,452 were non-sickness present (43.0\%). Most commonly, we observed sickness presence in women aged less than 50 who finished primary or secondary school and whose net salary amounts to less than 1,000 EUR. Among the selected stressful life events that were included in the multivariate logistic regression, there was the strongest association between sickness presence and the presence of disease in a family member (Table 1).

\section{DISCUSSION}

At the UMC Ljubljana, the share of the sickness present is comparable to the share mentioned in other studies $(3,5,6,16,20)$. The data gathered in our study suggest that the risk for sickness presence at the UMC Ljubljana does not differ between genders, which is in line with the findings of Lavella et al. (21), but the results of the studies carried out throughout the world differ (3, 4, $7,8)$. As regards the age of the sickness present, different studies yield different results $(3,4,15)$. Our study shows that the odds for sickness presence are more displayed in workers aged less than 50 .
There is a greater number of sickness present among employees with a lower level of education and lower salary, which is also in accordance with the results of our study $(3,4,22,23)$.

For the first time, stressful life events influencing sickness presence were systematically included in the study. The researchers estimate that stressful life events affect both, sickness presence and sickness absence, the decision depends upon the workers themselves (24). There have been many changes in local economy after the independence of Slovenia in 1991, one of the most important changes observed was the insecurity to get permanent and well paid job (25). It is estimated that people start to behave differently due to survival reasons. Economic transition, crisis and a decreased likelihood of permanent employment with the possibility of dismissal and a decrease in salary during sick leave influenced workers to adapt to the new survival conditions (25). In our study the association between sickness presence and disease of a relative, partner's loss of employment and the repayment of the loan confirmed the economic dimensions of the phenomenon of sickness presence $(3,4,10)$. In case of disease of a family member, their contribution to the household budget is smaller due to their inability to work and/or due to a lower salary in case of sick leave, while their needs are greater due to disease. The partner's loss of employment also decreases the household budget. The loan, however, demands a more substantial monthly outflow. In all three cases, the presence at work even when sick is an existential need. The sickness absence itself brings lower income and the financial distress and is therefore greater in groups with lower salaries. Further, employees with a lower level of education such as nursing auxiliaries and state enrolled nurses are at higher risk of sickness presence $(3,4)$. Change in residency probably requires more money to equip new accommodation, and additional costs incurred to cover expenses for travel to work.

There is a slight risk of sickness presence in case when a child is leaving home. It might be a specific situation in case of high rate of young people unemployment. At the end of 2010, more than $16 \%$ of all unemployed people in Slovenia had no work experience at all and the rate of unemployed young people is among the highest in the European Union (26). All these young people burden their parents to cover their substantial needs even when they leave home. It has been established that also adult education paid by the employer raised the odds for sickness presence. The obligation to study besides the regular work is a double burden which brings higher psychological demands and time pressure, so these factors are associated with sickness presence as well $(17,27,28)$.

Finally, according to the results, the personal situation including stressful life events and the personal attitude to one's own health status seems to be important in decision of the worker whether to take sick leave or not $(29,30)$. The pressure when making decision about sickness presence or sickness absence is usually exerted by the worker himself (31).

Despite the fact that the responsiveness of the participants was good and comparable to other studies on sickness presence, this study has its limitations. The test subjects took part in the research on a voluntary basis, therefore, not all the workers were included, but their response was in line with other studies mentioned. As regards the circumstances in Slovenia, the response was good. The analysis of respondents and non-respondents did not show significant differences between these two groups so we 
Table 1. Estimates of sickness presence according to the selected variables among health care workers at the University Medical Centre Ljubljana, 2010, and the results of the multivariate logistic regression

\begin{tabular}{|c|c|c|c|c|c|c|c|}
\hline \multirow{2}{*}{ Risk factor } & \multirow{2}{*}{ Category } & \multicolumn{2}{|c|}{$\mathrm{N}=3,379$} & \multirow{2}{*}{ OR } & \multicolumn{2}{|c|}{$95 \%$ Cl limits } & \multirow{2}{*}{$p$} \\
\hline & & NSP/Ncat & $\%$ & & Lower & Upper & \\
\hline \multirow[t]{2}{*}{ Gender } & Male & $293 / 558$ & 52.5 & 1.00 & \multirow{2}{*}{0.94} & \multirow{2}{*}{1.37} & \multirow{2}{*}{0.203} \\
\hline & Female & $1,634 / 2,821$ & 57.9 & 1.13 & & & \\
\hline \multirow[t]{2}{*}{ Age } & 50 years or more & $417 / 822$ & 47.3 & 1.00 & \multirow{2}{*}{1.26} & \multirow{2}{*}{1.77} & \multirow{2}{*}{$<0.001$} \\
\hline & Less than 50 years & $1,510 / 2,557$ & 59.1 & 1.49 & & & \\
\hline \multirow[t]{2}{*}{ Education } & Higher or university & $797 / 1,842$ & 43.3 & 1.00 & \multirow{2}{*}{1.11} & \multirow{2}{*}{1.64} & \multirow{2}{*}{0.003} \\
\hline & Secondary or less & $1,130 / 1,537$ & 73.5 & 1.35 & & & \\
\hline \multirow[t]{2}{*}{ Children } & No & $510 / 951$ & 53.6 & 1.00 & \multirow{2}{*}{1.07} & \multirow{2}{*}{1.49} & م00 \\
\hline & Yes & $1,417 / 2,428$ & 58.4 & 1.27 & & & 0.000 \\
\hline Current smoker & No & $1,373 / 2,511$ & 54.7 & 1.00 & 111 & 155 & 0077 \\
\hline & Yes & $554 / 868$ & 63.8 & 1.31 & 1.11 & 1.50 & 0.041 \\
\hline Sport participation & No & $206 / 314$ & 65.6 & 1.00 & 05 & 001 & 000 \\
\hline & Yes & $1,721 / 3,065$ & 56.2 & 0.70 & 0.50 & 0.91 & 0.000 \\
\hline Net salary $<1,000$ EUR & No & $897 / 1,664$ & 53.9 & 1.00 & 001 & 110 & 000 \\
\hline & Yes & $1,030 / 1,715$ & 60.1 & 0.98 & 0.81 & 1.18 & 0.818 \\
\hline Death of close family member & No & $1,471 / 2,615$ & 56.2 & 1.00 & 007 & 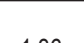 & 0 \\
\hline & Yes & $456 / 764$ & 59.7 & 1.15 & 0.91 & 1.30 & 0.118 \\
\hline Divorce & No & $1889 / 3,305$ & 57.2 & 1.00 & مP & 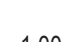 & D \\
\hline & Yes & $38 / 74$ & 51.4 & 0.62 & 0.39 & 1.00 & 0.052 \\
\hline Marriage & No & $1,844 / 3,236$ & 57.0 & 1.00 & 067 & 130 & 0815 \\
\hline & Yes & $83 / 143$ & 58.0 & 0.97 & 0.01 & 1.30 & 0.045 \\
\hline Birth of a child & No & $1,810 / 3,188$ & 56.8 & 1.00 & 00 & 10 & 000 \\
\hline & Yes & $117 / 191$ & 61.3 & 1.17 & 0.00 & 1.00 & 0.040 \\
\hline Child leaving home & No & $1,803 / 3,185$ & 56.6 & 1.00 & 000 & 101 & 000 \\
\hline & Yes & $124 / 194$ & 63.9 & 1.34 & 0.50 & $1.0 \mathrm{~J}$ & 0.000 \\
\hline Disease of a family member & No & $1,722 / 3,075$ & 56.0 & 1.00 & 117 & 100 & ?ח0? \\
\hline & Yes & $205 / 304$ & 67.4 & 1.51 & 1.11 & 1.90 & 0.002 \\
\hline Change of the workplace & No & $1,683 / 2,950$ & 57.1 & 1.00 & 77 & 117 & 050 \\
\hline & Yes & $244 / 429$ & 56.9 & 0.94 & 0.15 & 1.17 & 0.050 \\
\hline Change in responsibility at the workplace & No & $1,628 / 2,883$ & 56.5 & 1.00 & 400 & 150 & 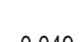 \\
\hline & Yes & $299 / 496$ & 60.3 & 1.24 & 1.00 & 1.53 & 0.049 \\
\hline Change in working time & No & $1,700 / 3,003$ & 56.6 & 1.00 & م00 & s & م \\
\hline & Yes & $227 / 376$ & 60.4 & 1.11 & 0.88 & 1.41 & 0.381 \\
\hline Additional adult education & No & $1,710 / 3,031$ & 56.4 & 1.00 & 400 & 101 & 000 \\
\hline & Yes & $217 / 348$ & 62.4 & 1.27 & 1.00 & 1.61 & 0.049 \\
\hline Change in the employment status of a & No & $1,763 / 3,131$ & 56.3 & 1.00 & 102 & 170 & 0035 \\
\hline & Yes & $164 / 248$ & 66.1 & 1.35 & 1.02 & 1.19 & 0.035 \\
\hline Loan & No & $1,457 / 2,652$ & 54.9 & 1.00 & 4 & 4 & (5) \\
\hline & Yes & $470 / 727$ & 64.6 & 1.38 & 1.15 & 1.00 & -0.001 \\
\hline Change in living conditions & No & $1707 / 3,015$ & 56.6 & 1.00 & $0 \subset 7$ & 110 & 0100 \\
\hline & Yes & $220 / 364$ & 60.4 & 0.89 & & & 0.400 \\
\hline Change of residency & No & $1,753 / 3,114$ & 56.3 & 1.00 & 100 & 100 & קחסק \\
\hline & Yes & $174 / 265$ & 65.7 & 1.41 & 1.02 & 1.90 & 0.039 \\
\hline Change in recreation & No & $1,615 / 2,864$ & 56.4 & 1.00 & 009 & 140 & 0063 \\
\hline & Yes & $312 / 515$ & 60.6 & 1.21 & 0.99 & 1.49 & 0.003 \\
\hline Vacation & No & $1,061 / 1,792$ & 59.2 & 1.00 & 075 & 007 & 000 \\
\hline & Yes & $866 / 1,587$ & 54.6 & 0.86 & 0.15 & 0.91 & 0.045 \\
\hline
\end{tabular}

NSP = number of sickness present in the group; Ncat = number of sickness present in the category

Abbreviations $\mathrm{OR}$ - odds ratio; $\mathrm{Cl}$ - confidence interval 
cannot find any reason why $40 \%$ of the non-respondents could be considered so different from the respondents that the results of this study cannot be evaluated as reliable.

This study is important for occupational health, because it poses two questions. The first question concerns the importance of sickness presence as the possible new indicator of workers' health, the second one addresses employers and general society to help workers to get over their crucial life events to keep their workability.

\section{CONCLUSIONS}

Sickness present workers represent a large group among employed health care workers. It is obvious that besides other risk factors stressful life events that influence the existential needs or reduce the living standard contribute to the decision for sickness presence among the health care workers. The findings give direction for future interventions. Not only the companies but also the society needs to be involved to make improvements to promote the proper rehabilitation of sick people regardless of their economic and financial situation.

\section{Conflict of Interests}

None declared

\section{Sponsorship}

As a tertiary project, the study was co-financed by the Health Insurance Institute of Slovenia (Project No. 20110043).

\section{Ethical Recommendations}

The study was approved by the National Medical Ethics Committee of the Republic of Slovenia on 11 January 2011.

\section{REFERENCES}

1. The Swedish Ministry of Health and Social Affairs. The health of Swedish people. In: HS 90 Health in Sweden. Stockholm: 1982. p. 31-47.

2. McKevitt C, Morgan M, Dundas R, Holland WW. Sickness absence and 'working through' illness: a comparison of two professional groups. J Public Health Med. 1997 Sep;19(3):295-300.

3. Aronsson G, Gustafsson K, Dallner M. Sick but yet at work. An empirical study of sickness presenteeism. J Epidemiol Community Health. 2000 Jul;54(7):502-9.

4. Aronsson G, Gustafsson K. Sickness presenteeism: prevalence, attendance-pressure factors, and an outline of a model for research. J Occup Environ Med. 2005 Sep;47(9):958-66.

5. Bergström G, Bodin L, Hagberg J, Aronsson G, Josephson M. Does sickness presenteeism have an impact on future general health? Int Arch Occup Environ Health. 2009 Nov;82(10):1179-90.

6. Bergström G, Bodin L, Hagberg J, Lindh T, Aronsson G, Josephson M. Sickness presenteeism today, sickness absenteeism tomorrow? A prospective study on sickness presenteeism and future sickness absenteeism. J Occup Environ Med. 2009 Jun;51(6):629-38.

7. Johns G. Presenteeism in the workplace: a review and research agenda. J Organ Behav. 2010 May;31(4):519-42.

8. Demerouti E, Le Blanc PM, Bakker AB, Schaufeli WB, Hox J. Present but sick: a three-wave study on job demands, presenteeism and burnout. Career Dev Int. 2009;14(1):50-68.

9. Vahtera J, Kivimäki M, Pentti J, Linna A, Virtanen M, Virtanen P, Ferrie JE. Organizational downsizing, sickness absence, and mortality: 10-town prospective cohort study. BMJ. 2004 Mar 6;328(7439):555.
10. Johansson G, Lundberg I. Adjustment latitude and attendance requirements as determinants of sickness absence or attendance. Empirical tests of the illness flexibility model. Soc Sci Med. 2004 May;58(10):1857-68.

11. Dew K, Keefe V, Small K. 'Choosing' to work when sick: workplace presenteeism. Soc Sci Med. 2005 May;60(10):2273-82.

12. Callen BL, Lindley LC, Niederhauser VP. Health risk factors associated with presenteeism in the workplace. J Occup Environ Med. 2013 Nov;55(11):1312-7.

13. Berdavs A, Stanojević M. Work and leisure in USA and Slovenia [diploma thesis]. Ljubljana: University of Ljubljana; 2008. p. 36-55. (In Slovenian.)

14. Caverley N, Cunningham JB, MacGregor JN. Sickness presenteeism, sickness absenteeism, and health following restructuring in a public service organization. J Manage Stud. 2007 Mar;44(2):304-19.

15. Heponiemi T, Elovainio M, Pentti J, Virtanen M, Westerlund H, Virtanen $\mathrm{P}$, et al. Association of contractual and subjective job insecurity with sickness presenteeism among public sector employees. J Occup Environ Med. 2010 Aug;52(8):830-5.

16. Elstad JI, Vabø M. Job stress, sickness absence and sickness presenteeism in Nordic elderly care. Scand J Public Health. 2008 Jul;36(5):467-74.

17. Rantanen I, Tuominen R. Relative magnitude of presenteeism and absenteeism and work-related factors affecting them among health care professionals. Int Arch Occup Environ Health. 2011 Feb;84(2):225-30.

18. Holmes TH, Rahe RH. The social readjustment rating scale. J Psychosom Res. 1967 Aug;11(2):213-8.

19. Merchant JA, Kelly KM, Burmeister LF, Lozier MJ, Amendola A, Lind DP, et al. Employment status matters: a statewide survey of quality-oflife, prevention behaviors, and absenteeism and presenteeism. J Occup Environ Med. 2014 Jul;56(7):686-98.

20. Jena AB, Baldwin DC Jr, Daugherty SR, Meltzer DO, Arora VM. Presenteeism among resident physicians. JAMA. 2010 Sep 15;304(11):1166-8.

21. LaVella S, Goldenstein B, Smith B, Weaver FM. Working with symptoms of a respiratory infection: staff who care for high-risk individuals. Am J Infect Control. 2007 Sep;35(7):448-54.

22. Notenbomer A, Roelen CA, Groothoff JW. Job satisfaction and shortterm sickness absence among Dutch workers. Occup Med (Lond). 2006 Jun;56(4):279-81

23. Gustafsson K, Marklund S. Consequences of sickness presence and sickness absence on health and work ability: a Swedish prospective cohort study. Int J Occup Med Environ Health. 2011 Jun;24(2):153-65.

24. MacGregor JN, Cunningham JB, Caverley N. Factors in absenteeism and presenteeism: life events and health events. Manag Res News. 2008;31(8):607-15.

25. Dodič Fikfak M. Health of the people in time of crisis. Ljubljana: Glasnik KIMDPŠ; 2010. (In Slovenian.)

26. Eurostat [Internet]. Luxembourg: European Commission; 2015 [cited 2015 Mar 7]. Unemployment rate by age group. Available from: http:// ec.europa.eu/eurostat/tgm/table.do?tab=table\&init=1\&language=en \&p code $=$ tsdec 460 \&plugin $=1$.

27. Hansen CD, Andersen JH. Going ill to work - what personal circumstances, attitudes and work-related factors are associated with sickness presenteesim? Soc Sci Med. 2008 Sep;67(6):956-64.

28. Claes R. Employee correlates of sickness presence: a study across four European countries. Work Stress. 2011;25(3):224-42.

29. Richard I, Huver B, Richard S. Working when sick: do managers lead by example. In: Tsounis N, Vlachvei A, Gaetano M, Monovasilis T, eds. Proceedings: International Conference On Applied Economics 2011 [Internet]. Kastoria: TEI of Wester Macedonia Press; 2011 [cited 2014 Oct 9]. Available from: http://kastoria.teikoz.gr/icoae2/wordpress/wpcontent/uploads/2011/10/054.pdf.

30. Sampere M, Gimeno D, Serra C, Plana M, Martínez JM, Delclos GL, et al. Organizational return to work support and sick leave duration: a cohort of Spanish workers with a long-term non-work-related sick leave episode. J Occup Environ Med. 2011 Jun;53(6):674-9.

31. Schreuder JA, Roelen CA, van der Klink JJ, Groothof JW. Characteristic of zero-absenteeism in hospital care. Occup Med (Lond). 2013 Jun;63(4):266-73.

Received November 3, 2014 Accepted in revised form March 9, 2015 